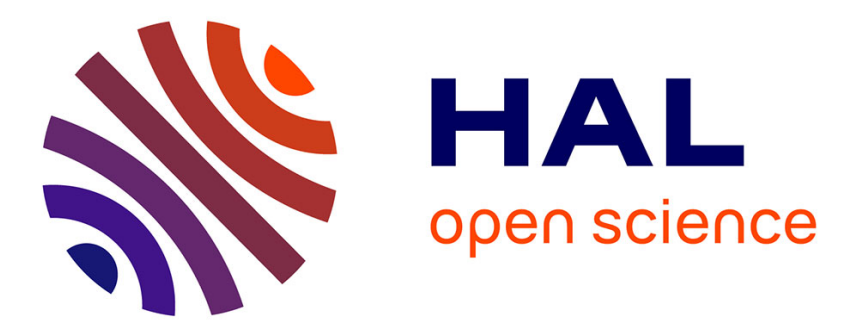

\title{
Yield potential and land-use efficiency of wheat and faba bean mixed intercropping
}

Getachew Agegnehu, Amare Ghizaw, Woldeyesus Sinebo

\section{To cite this version:}

Getachew Agegnehu, Amare Ghizaw, Woldeyesus Sinebo. Yield potential and land-use efficiency of wheat and faba bean mixed intercropping. Agronomy for Sustainable Development, 2008, 28 (2), pp.257-263. hal-00886401

\section{HAL Id: hal-00886401 https://hal.science/hal-00886401}

Submitted on 1 Jan 2008

HAL is a multi-disciplinary open access archive for the deposit and dissemination of scientific research documents, whether they are published or not. The documents may come from teaching and research institutions in France or abroad, or from public or private research centers.
L'archive ouverte pluridisciplinaire HAL, est destinée au dépôt et à la diffusion de documents scientifiques de niveau recherche, publiés ou non, émanant des établissements d'enseignement et de recherche français ou étrangers, des laboratoires publics ou privés. 


\title{
Yield potential and land-use efficiency of wheat and faba bean mixed intercropping
}

\author{
Getachew AgEgneHU*, Amare GHIZAW, Woldeyesus Sinebo \\ Holetta Agricultural Research Centre, Ethiopian Institute of Agricultural Research, PO Box 2003, Addis Ababa, Ethiopia
}

(Accepted 11 February 2008)

\begin{abstract}
In Ethiopia, food production for a rapidly growing population from a continually shrinking farm size is a prime developmental challenge. Rising input costs, decline in soil quality, and buildup of insect pests, diseases and weeds have threatened the ecological and economic sustainability of crop production. To address those issues, intercropping of cereals with pulse crops could increase total grain production, provide diversity of products, stabilize yield over seasons, reduce economic and environmental risks common in monoculture systems, and thereby enhance sustainability. Here, mixed intercropping of wheat (Triticum aestivum L.) with faba bean (Vicia faba L.) was compared with sole culture of each species in 2002 and 2003 at Holetta Agricultural Research Center, in the central highlands of Ethiopia. The treatments were sole wheat at a seed rate of $175 \mathrm{~kg} \mathrm{ha}^{-1}$, sole faba bean at a seed rate of $200 \mathrm{~kg} \mathrm{ha}^{-1}$, and an additive series of $12.5,25,37.5,50$ and $62.5 \%$ of the sole faba bean seed rate mixed with the full sole wheat seed rate. Our results showed that mixed intercropping increased the land equivalent ratio by $+3 \%$ to $+22 \%$ over sole cropping. Increasing the faba bean seed rate in the mixture from 12.5 to $62.5 \%$ reduced wheat grain yield from $3601 \mathrm{~kg} \mathrm{ha}^{-1}$ to $3039 \mathrm{~kg} \mathrm{ha}^{-1}$ but increased faba bean grain yield from $141 \mathrm{~kg} \mathrm{ha}^{-1}$ to $667 \mathrm{~kg} \mathrm{ha}^{-1}$. Sole culture grain yield exceeded mixed culture grain yield by +5 to $+25 \%$ for wheat and by +172 to $+1190 \%$ for faba bean. Nonetheless, we obtained the highest total grain yield of $4031 \mathrm{~kg} \mathrm{ha}^{-1}$, gross monetary value of US\$ 823, system productivity index of 4629 and crowding coefficient of 4.70 when wheat at its full seed rate was intercropped with faba bean at a rate of $37.5 \%$. On average, weed biomass was reduced from $40.4 \mathrm{~g} \mathrm{~m}^{-2}$ in sole wheat to $31.1 \mathrm{~g} \mathrm{~m}^{-2}$ in mixed culture and the chocolate spot disease score was reduced from 5.1 in sole faba bean to 3.4 in mixed culture. In conclusion, intercropping of wheat with faba bean may increase total yield and revenue, reduce weed and disease pressure, increase land-use efficiency, and thereby enhance sustainability of crop production in Ethiopian highlands.
\end{abstract}

aggressivity / crowding coefficient / faba bean / land-use efficiency / intercropping / wheat

\section{INTRODUCTION}

In the tropics, cereal/legume intercropping is a common practice aimed at minimizing risks associated with monoculture. Intercropping may provide a balanced diet, reduce labor peaks, minimize crop failure due to adverse effects of biotic and abiotic factors, protect soil against erosion, improve the use of limited resources, increase stability of yield and provide higher returns (Willey, 1979; Beets, 1982; Jensen, 1996; Akter et al., 2004; Chu et al., 2004; Tsubo et al., 2005). Productivity advantages of intercropping may arise from complementary use of growth resources such as $\mathrm{N}$ and water in either space or time (Willey, 1979; Ofori and Stern, 1987; Benites et al., 1993; Akter et al., 2004; Chu et al., 2004). Moreover, productivity of mixtures could exceed those of sole crops, as the mixing of the two crops may favor more significant yield components in either crop (Willey, 1979; Kurdali et al., 1996).

*Corresponding author: get491663@yahoo.com
In the same manner and elsewhere, the beneficial effects of intercropping of wheat with legumes was ascribed to the more efficient use of environmental resources by the intercrops than by pure stands (Banik, 1996; Bulson et al., 1997; Haymes and Lee, 1999).

Measurements such as the total yield, total revenue, land equivalent ratio, crowding coefficient, aggressivity value and system productivity index have been used to quantify the efficiency of intercropping systems relative to sole cropping (Rao and Willey, 1980; Hiebsch and McCollum, 1987; Agegnehu et al., 2006a, b). However, the land equivalent ratio is the mostused convention for intercrop vs. sole crop comparisons. This may stem from the fact that increasing land-use efficiency is the most important reason for producing crops in intercrop.

In Ethiopia, food production for a rapidly growing population from a continually shrinking farm size is a prime developmental challenge. The central highlands of Ethiopia are typified by a subsistence-oriented crop-livestock mixed farming 
system where cereal-based cropping systems dominate. Wheat and faba bean are two of the major crops grown by subsistence farmers under rain-fed conditions in Ethiopia. The area under wheat in the main season is about 1.1 million ha, making up $15.7 \%$ of the total cereal area (CSA, 2004). Faba bean is the most important grain legume in Ethiopia in terms of area and production. It is a major source of protein and a beneficial break crop for ameliorating soil fertility in a cereal-based cropping system. About 0.38 million ha is covered by faba bean, making up 34.7\% of the total area allotted to pulses in Ethiopia (CSA, 2004).

In the highlands of Ethiopia, the advent and expansion of high fertilizer-input and semi-dwarf wheat varieties for nearly four decades now is a dominant feature of crop agriculture. However, rising input costs, decline in farm size and soil quality, and buildup of insect pests, diseases and weeds have threatened the ecological and economic sustainability of wheat production in these highlands. Growing crops in mixtures is a common practice in traditional agriculture in various parts of Ethiopia (Georgis et al., 1990). Nonetheless, pure culture of high-yielding and high fertilizer-input varieties have been promoted for several decades now as a way of enhancing food production in the country. Despite this, a recent recourse by farmers in northern Ethiopia from growing a pure crop of improved varieties of semi-dwarf wheat to mixed intercropping of these wheats with a small population of each of faba bean and field pea has attracted attention from research and development stakeholders. The farmers' reason for such a practice is land shortage coupled with the need to produce a cereal crop in the main and some pulse as an additional benefit, enabling land intensification where arable land scarcity is fast becoming very crucial. However, such practices are not common in the central highlands of Ethiopia where both wheat and faba bean are widely grown in increasingly declining farm sizes. Promotion of intercropping modern semi-dwarf wheat with faba bean requires generation of research information on the agronomic, ecological and economic feasibility of introducing such systems into the diverse farming systems, particularly of the central Ethiopian highlands. We have already reported research results on the feasibility of intercropping of barley (Hordeum vulgare L.) and tef (Eragrostis tef) with faba bean elsewhere (Agegnehu et al., 2006a, b). The objectives of the present study were, therefore, to evaluate the agronomic performance of wheat and faba bean in intercrop, to determine the biological and economic optimum combination for intercropping, and to infer the likely ecological advantages of intercropping these crops.

\section{MATERIALS AND METHODS}

\subsection{Study area}

An experiment on the intercropping of wheat and faba bean was undertaken in the 2002 and 2003 cropping seasons under rain-fed conditions on eutric Nitisol at Holetta Agricultural Research Center, central highlands of Ethiopia. The location of the trial site is between $09^{\circ} 03^{\prime} \mathrm{N}$ latitude and $38^{\circ} 30^{\prime} \mathrm{E}$ longitude at an altitude of $2390 \mathrm{~m}$ above sea level. The long-term average annual precipitation is $1100 \mathrm{~mm}$, about $85 \%$ of which is received from June to September, and average minimum and maximum air temperatures are 6.1 and $21.9^{\circ} \mathrm{C}$, respectively. Experimental fields were ploughed using tractor-drawn implements. Soil physical and chemical properties of the experimental fields were determined for samples taken during planting. The soil at 0-30 cm depth had a clay content of 56.06\%, a silt content of $28.58 \%$ and a sand content of $15.36 \%$. The $\mathrm{pH}$ $\left(1: 1 \mathrm{H}_{2} \mathrm{O}\right)$ was 5.12 , organic $\mathrm{C}$ (Walkley-Black) $1.85 \%$, total $\mathrm{N}$ (Kjeldahl) $0.17 \%, \mathrm{NO}_{3}-\mathrm{N} 8.37 \mathrm{ppm}$ and $\mathrm{P}$ (Bray-II) $7.84 \mathrm{ppm}$. The Na content was $0.08, \mathrm{~K} 1.56, \mathrm{Ca} 2.76, \mathrm{Mg} 2.16$ and CEC 24.46 (all in meq $100 \mathrm{~g}^{-1}$ soil using the ammonium acetate pH 7.0 method).

\subsection{Field experiment}

The treatments were an additive series of mixed intercropping of faba bean in wheat at seed rates of $12.5,25,37.5,50$ or $62.5 \%$ of the sole faba bean seed rate $\left(200 \mathrm{~kg} \mathrm{ha}^{-1}\right)$ plus sole cultures of the two crops as checks. A full seed rate of $175 \mathrm{~kg} \mathrm{ha}^{-1}$ was used for wheat both in sole and mixed culture. The design was a randomized complete block with four replications. Experimental plots of pure wheat and intercrops received the recommended rate of $64 / 20 \mathrm{~kg} \mathrm{NP} \mathrm{ha}^{-1}$ for wheat in the form of urea and diammonium phosphate, while pure faba bean plots received 18/20 $\mathrm{kg} \mathrm{NP} \mathrm{ha}^{-1}$ as diammonium phosphate at planting.

Wheat (Triticum aestivum L.) cultivar HAR 604 and faba bean (Vicia faba L.) cultivar CS20DK, a minor type, were sown at the same time at the optimum planting date for wheat. A plot size of $5 \mathrm{~m}$ by $5 \mathrm{~m}$ was used. Sowing took place on 22 and 24 June in 2002 and 2003, respectively. Pulses were the preceding crops in both seasons. Weeds were pulled once by hand 5 weeks after crop emergence. Data collected were plant stand counts $\mathrm{m}^{-2}$ at complete emergence, plant height (average of 10 plants), number of tillers $\mathrm{m}^{-2}$, seeds per spike, number of pods per plant and seeds per pod, aboveground biomass and grain yields, and thousand-grain weight of each crop species as appropriate.

Weed biomass was collected from a quadrat measuring $0.5 \mathrm{~m}$ by $0.5 \mathrm{~m}$ thrown at random on two sampling points in each plot at the time of weeding, oven-dried and expressed as $\mathrm{g} \mathrm{m}^{-2}$. Septoria disease assessment on wheat was made when the crop was between the medium to late milk growth stages using the double-digit 00-99 scale, where the first digit gives the relative height of the disease and the second digit shows the disease severity as a percentage (Eyal et al., 1987). Chocolate spot disease (Botrytis fabae Sard.) of faba bean was recorded on a 1-9 scale, where 1 indicates no disease symptoms or very small specks on leaves and 9 extensive lesions on leaves, stems and flowers. Crops of the mixed cultures were harvested separately for each crop from the whole plot. After threshing, seeds were cleaned, weighed and adjusted at the $12 \%$ and $10 \%$ moisture levels for wheat and faba bean, respectively. Wheat was considered as the main crop and faba bean as an intercrop component. Total biomass and grain yields recorded on a plot basis were converted to $\mathrm{kg} \mathrm{ha}^{-1}$ for statistical analysis. 


\subsection{Statistical analysis}

The SAS/STAT computer package version 8.2 (SAS Institute, 2001) was used to test for the presence of outliers and normality of residuals. The total variability for each trait was quantified using pooled analysis of variance over years using the following model.

$$
P_{i j k}=\mu+Y_{i}+R_{j(i)}+T_{k}+T Y_{(i k)}+e_{i j k}
$$

where $P_{i j k}$ is total observation, $\mu=$ the grand mean, $Y_{i}=$ the effect of the ith year, $R_{j(i)}$ is the effect of the jth replication within the ith year, $T_{k}$ is the effect of the $k$ th treatment, $T Y_{(i k)}$ is the interaction of the $k$ th treatment with the $i$ th year and $e_{i j k}$ is the random error. Least significant difference at the 5\% probability level was used to establish the difference among the means. Gross monetary value was determined based on the average prices of wheat (US $\$ 0.193 \mathrm{~kg}^{-1}$ ) and faba bean (US $\$ 0.223 \mathrm{~kg}^{-1}$ ).

\subsection{Calculation of yield advantages and competitive relationships}

The index commonly used to evaluate the relative advantage of intercropping compared with sole culture is the total land equivalent ratio, i.e. the relative land area required by sole crops to produce the yields achieved in intercropping (Rao and Willey, 1980), which is calculated as:

$$
\text { Land Equivalent Ratio }=\frac{Y_{a}}{Y_{A}}+\frac{Y_{b}}{Y_{B}}
$$

where $Y_{a}$ and $Y_{b}$ are the component yields of crops A (wheat) and $\mathrm{B}$ (faba bean) in intercropping, and $Y_{A}$ and $Y_{B}$ are the yields of sole cultures of $\mathrm{A}$ and $\mathrm{B}$ on a similar unit area. A land equivalent ratio of 1.0 indicates equal advantages for intercropping and sole cropping, values more than 1.0 indicate more advantage for intercropping than for sole cropping and values less than 1.0 indicate less advantage for intercropping than for sole cropping. The competitive relationship between the two crops was determined using the crowding coefficient $(k)$ and aggressivity value (A) suggested by Willey (1979) as:

$$
\begin{aligned}
& \text { Crowding coef ficient of wheat }\left(K_{a b}\right)=\frac{Y_{a b} \times Z_{b a}}{\left(Y_{a a}-Y_{a b}\right) \times Z_{a b}} \\
& \text { Crowding coefficient of fababean }\left(K_{b a}\right)=\frac{Y_{b a} \times Z_{a b}}{\left(Y_{b b}-Y_{b a}\right) \times Z_{b a}} \\
& \text { Aggresivity of wheat }\left(A_{a b}\right)=\frac{Y_{a b}}{Y_{a a} \times Z_{a b}}-\frac{Y_{b a}}{Y_{b b} \times Z_{b a}} \\
& \text { Aggresivity of fababean }\left(A_{b a}\right)=\frac{Y_{b a}}{Y_{b b} \times Z_{b a}}-\frac{Y_{a b}}{Y_{a a} \times Z_{a b}}
\end{aligned}
$$

where $Y_{a a}=$ pure culture yield of wheat, $Y_{b b}=$ pure culture yield of faba bean, $Y_{a b}=$ mixed culture yield of wheat, $Y_{b a}$ $=$ mixed culture yield of faba bean, $Z_{a b}=$ sown proportion of wheat and $Z_{b a}=$ sown proportion of faba bean. Another index for assessing intercrops is the system productivity index (SPI), presented by Odo (1991), which standardizes the yield of the secondary crop, $b$, in terms of the primary crop, $a$.

$$
S P I=\frac{S_{a}}{S_{b}} Y_{b}+Y_{a}
$$

where $S_{a}$ and $S_{b}=$ mean yield of wheat and faba bean in sole culture, and $Y_{a}$ and $Y_{b}=$ mean yield of wheat and faba bean in mixed culture.

\section{RESULTS AND DISCUSSION}

\subsection{Growth and yields of component crops}

Wheat grain yield was $101 \%$ and faba bean grain yield $80 \%$ greater in 2003 than in 2002 (Tab. I). Also, on average, plants of each species grew taller and biomass yields were greater in 2003 than in 2002 (Tabs. II, III). This is because 2003 had better precipitation than 2002 during grain filling. There was a terminal low moisture stress beginning the last week of September in 2002. However, the Septoria disease score on wheat, chocolate spot disease incidence on faba bean and weed infestation were significantly lower in 2003 than in 2002.

Intercropping effects were significant $(P \leqslant 0.01)$ for grain yields of each crop species (Tab. I). On average, sole wheat yielded 3801 and sole faba bean $1819 \mathrm{~kg} \mathrm{ha}^{-1}$. The mean faba bean seed yield decreased from $667 \mathrm{~kg} \mathrm{ha}^{-1}$ to $141 \mathrm{~kg} \mathrm{ha}^{-1}$ and wheat yield increased from 3039 to $3601 \mathrm{~kg} \mathrm{ha}^{-1}$ when the faba bean seed rate in the intercrop decreased from 62.5 to $12.5 \%$ of the sole faba seed rate (Tab. I). The highest total intercrop yield of $4031 \mathrm{~kg} \mathrm{ha}^{-1}$ and gross monetary value of US $\$ 823$ were obtained when faba bean at the rate of $37.5 \%$ was mixed with full wheat (Tab. I). The gross monetary value followed the same trend as the total land equivalent ratio. On the basis of seeding percentage in the mixtures, none of the mixed proportions produced relative yields of faba bean similar to the expected yields.

On average, weed biomass was reduced from $40.4 \mathrm{~g} \mathrm{~m}^{-2}$ in sole wheat to $31.1 \mathrm{~g} \mathrm{~m}^{-2}$ in mixed culture and chocolate spot disease score from 5.1 in sole faba bean to 3.4 in mixed culture. This also agrees with the findings of Carr et al. (1995) for wheat/lentil intercrop, Bulson et al. (1997) for wheat/field bean intercropping, Holland and Brummer (1999) for oat/berseem clover intercropping and Agegnehu et al. (2006a, b) for barley/faba bean and tef/faba bean intercropping. The year by intercropping interaction effect was significant for faba bean grain yield. From the scrutiny of faba bean grain yields for individual years, this interaction arose from scale effects rather than rank changes, with a narrower yield gap between the two years for the $12.5 \%$ faba bean compared with the other faba bean seed rate treatments in the mixture.

In our study, although the growing of faba bean as a companion crop with wheat reduced the productivity of wheat, the mixed crops as a whole resulted in higher total productivity as measured by total grain yields of the two crops. Moreover, intercrops were more suppressive of weeds and diseases than either wheat or faba bean sole crops. Elsewhere, yield increments as a result of intercropping of two different crops (Rao 
Table I. Effects of intercropping on component grain yield, land equivalent ratio and gross monetary advantage of wheat and faba bean, 2002-2003.

\begin{tabular}{|c|c|c|c|c|c|c|}
\hline \multirow{2}{*}{ Factor } & \multicolumn{2}{|c|}{ Grain yield $\left(\mathrm{kg} \mathrm{ha}^{-1}\right)$} & \multicolumn{3}{|c|}{ Partial and total land equivalent ratios } & \multirow{2}{*}{ Gross monetary value (US $\$ \mathrm{ha}^{-1}$ ) } \\
\hline & Wheat & Faba bean & Wheat & Faba bean & Total & \\
\hline \multicolumn{7}{|l|}{ Year } \\
\hline 2002 & $2270 \mathrm{~b} \dagger$ & $487 \mathrm{~b}$ & $0.87 b$ & 0.40 & 1.27 & $566 \mathrm{~b}$ \\
\hline 2003 & $4568 \mathrm{a}$ & $877 \mathrm{a}$ & $0.92 \mathrm{a}$ & 0.36 & 1.28 & $1115 \mathrm{a}$ \\
\hline Significance level & $* *$ & $* *$ & $*$ & $*$ & NS & $* * *$ \\
\hline \multicolumn{7}{|l|}{ Intercropping } \\
\hline Sole wheat & $3801 \mathrm{a}$ & - & $1.000 \mathrm{a}$ & - & $1.00 \mathrm{~b}$ & $760 \mathrm{~b}$ \\
\hline Sole faba bean & - & $1819 \mathrm{a}$ & & $1.00 \mathrm{a}$ & $1.00 \mathrm{~b}$ & $418 \mathrm{c}$ \\
\hline Wheat/faba bean $(100: 12.5)$ & $3601 \mathrm{ab}$ & $141 \mathrm{e}$ & $0.95 b$ & $0.08 \mathrm{~d}$ & $1.03 \mathrm{~b}$ & $753 b$ \\
\hline Wheat/faba bean (100:25) & $3394 b c$ & $352 \mathrm{~d}$ & $0.89 \mathrm{bc}$ & $0.19 \mathrm{c}$ & $1.08 \mathrm{~b}$ & $760 \mathrm{~b}$ \\
\hline Wheat/faba bean (100:37.5) & $3482 b$ & $549 \mathrm{c}$ & $0.92 b$ & $0.30 \mathrm{~b}$ & $1.22 \mathrm{a}$ & $823 a$ \\
\hline Wheat/faba bean (100:50) & $3198 \mathrm{dc}$ & $574 \mathrm{bc}$ & $0.84 \mathrm{~cd}$ & $0.32 \mathrm{~b}$ & $1.16 \mathrm{ab}$ & $772 \mathrm{ab}$ \\
\hline Wheat/faba bean (100:62.5) & $3039 d$ & $667 b$ & $0.80 \mathrm{~d}$ & $0.37 \mathrm{~b}$ & $1.17 \mathrm{ab}$ & $761 b$ \\
\hline Significance level & $* * *$ & $* * *$ & $* *$ & $* *$ & $* *$ & $* * *$ \\
\hline $\operatorname{LSD}_{0.05}$ & 264.1 & 121.4 & 0.1 & 0.1 & 0.1 & 50.7 \\
\hline Year $\times$ intercropping & NS & $* *$ & NS & NS & NS & $* * *$ \\
\hline Coefficient of variation (\%) & 7.6 & 17.5 & 7.4 & 22.0 & 6.7 & 7.0 \\
\hline
\end{tabular}

1 US $\$=8.69$ Ethiopian Birr (ETB). $* * * * * *$ Significant at $P \leqslant 0.05, P \leqslant 0.01, P \leqslant 0.001$; NS = not significant. $\dagger$ Means in a column for treatments with the same letter are not significantly different at $P \leqslant 0.05$.

Table II. Intercropping effects on total biomass yield (TBY), thousand-kernel weight (TKW), kernel per spike (KPS), plant height (PHT), Septoria disease (SPT), tiller number, weed dry matter (WDM) and stand count (SC) of wheat grown in 2002 and 2003 in Holetta, Ethiopia.

\begin{tabular}{|c|c|c|c|c|c|c|c|c|}
\hline Factor & TBY $\left(\mathrm{kg} \mathrm{ha}^{-1}\right)$ & TKW (g) & KPS (no.) & PHT $(\mathrm{cm})$ & SPT $(\%)$ & Tillers $\left(\mathrm{m}^{-2}\right)$ & WDM $\left(\mathrm{g} \mathrm{m}^{-2}\right)$ & $\mathrm{SC}\left(\mathrm{m}^{-2}\right)$ \\
\hline \multicolumn{9}{|l|}{ Year } \\
\hline 2002 & 8072 & 38.5 & 58 & 102 & 81 & 311 & 41.3 & 133 \\
\hline 2003 & 12395 & 36.5 & 49 & 114 & 63 & 327 & 24.0 & 291 \\
\hline Level of significance & $* * *$ & NS & $* *$ & $* *$ & $* *$ & NS & $* *$ & $* *$ \\
\hline \multicolumn{9}{|l|}{ Intercropping } \\
\hline Sole wheat & $10921 \mathrm{a} \dagger$ & 36.9 & 60 & 106 & 76 & 373 & $40.4 \mathrm{a}$ & 231 \\
\hline Wheat/faba bean $(100: 12.5)$ & $10829 \mathrm{a}$ & 37.7 & 51 & 107 & 75 & 314 & $34.6 a b$ & 212 \\
\hline Wheat/faba bean $(100: 25)$ & $10602 \mathrm{ab}$ & 36.2 & 53 & 105 & 74 & 332 & $28.5 b$ & 178 \\
\hline Wheat/faba bean (100:37.5) & $9910 \mathrm{ab}$ & 38.9 & 51 & 118 & 73 & 316 & $32.5 b$ & 234 \\
\hline Wheat/faba bean $(100: 50)$ & $9660 \mathrm{ab}$ & 38.5 & 58 & 106 & 74 & 280 & $31.2 \mathrm{~b}$ & 193 \\
\hline Wheat/faba bean (100:62.5) & $9480 b$ & 36.7 & 51 & 107 & 73 & 300 & $28.8 b$ & 221 \\
\hline Level of significance & NS & NS & NS & NS & NS & NS & $* *$ & NS \\
\hline Least significant difference ( $5 \%$ ) & 1318 & NS & NS & NS & NS & NS & 6.3 & NS \\
\hline Year $\times$ intercropping & NS & $*$ & NS & NS & $*$ & NS & NS & NS \\
\hline Coefficient of variation $(\%)$ & 12.7 & 6.6 & 17.5 & 11.5 & 3.6 & 21.4 & 19.0 & 23.3 \\
\hline
\end{tabular}

*, ** Significant at $P \leqslant 0.05, P \leqslant 0.01 ; \mathrm{NS}=$ not significant.

$\dagger$ Means in a column with the same letter are not significantly different at $P \leqslant 0.05$.

and Willey, 1980; Beets, 1982; Trenbath, 1983; Benites et al., 1993; Chen et al., 2004) were attributed mainly to the presence of complimentary effects, better resource-use efficiency of the mixed cultures over the sole cultures and buffering effects of the mixtures against diseases, insects and weeds.

\subsection{Land-use efficiency}

Differences among treatments were significant for total and partial land equivalent ratios (Tab. I). All intercrops had a greater land equivalent ratio than sole crops, with the total land equivalent ratios for intercrops ranging from 1.03 to 1.22 . This implies that intercropping of wheat and faba bean resulted in higher total production per unit area than the sole culture of each crop species. In experiments with the same faba bean intercropping treatments at the same location using barley or tef as the cereal component, Agegnehu et al. (2006a, b) reported greater total yields and land equivalent ratios for all intercrops than for sole crops. Similar results were reported for mixed cultures of wheat and field bean (Bulson et al., 1997; Haymes and Lee, 1999), pea and barley (Jensen, 1996), maize and faba bean (Li et al., 1999) and wheat and lentil (Singh et al., 1992; Akter et al., 2004). In our study, the range of the partial land 
Table III. Intercropping effects on total biomass yield (TBY), thousand-seed weight (TSW), seeds per pod (SPP), pods per plant (PPP), plant height (PHT), chocolate spot (CSPT), and stand count (SC) of faba bean grown in 2002 and 2003 in Holetta, Ethiopia.

\begin{tabular}{|c|c|c|c|c|c|c|c|}
\hline Factor & TBY $\left(\mathrm{kg} \mathrm{ha}^{-1}\right)$ & TSW (g) & SPP (No.) & PPP (No.) & PHT $(\mathrm{cm})$ & CSPT (\%) & $\mathrm{SC}\left(\mathrm{m}^{-2}\right)$ \\
\hline \multicolumn{8}{|l|}{ Year } \\
\hline 2002 & 1471 & 577 & 2.5 & 6.9 & 127 & 4.1 & 37 \\
\hline 2003 & 1852 & 469 & 2.4 & 8.3 & 134 & 3.2 & 40 \\
\hline Level of significance & $* *$ & $* *$ & NS & $*$ & $*$ & $* *$ & NS \\
\hline \multicolumn{8}{|l|}{ Intercropping } \\
\hline Sole faba bean & $4555 \mathrm{a} \dagger$ & 533 & $2.6 a b$ & 8.2 & 134 & $5.1 \mathrm{a}$ & 34 \\
\hline Wheat/faba bean $(100: 12.5)$ & $489 d$ & 544 & $2.2 \mathrm{c}$ & 8.3 & 134 & $3.2 \mathrm{~b}$ & 11 \\
\hline Wheat/faba bean (100:25) & $751 \mathrm{~cd}$ & 523 & $2.6 \mathrm{ab}$ & 6.81 & 124 & $2.9 \mathrm{~b}$ & 15 \\
\hline Wheat/faba bean (100:37.5) & $1183 b c$ & 519 & $2.5 \mathrm{ab}$ & 7.8 & 128 & $3.9 \mathrm{ab}$ & 17 \\
\hline Wheat/faba bean (100:50) & $1411 b$ & 512 & $2.3 b c$ & 7.6 & 127 & $3.0 \mathrm{~b}$ & 21 \\
\hline Wheat/faba bean (100:62.5) & $1581 b$ & 507 & $2.8 \mathrm{a}$ & 6.7 & 134 & $3.8 \mathrm{ab}$ & 22 \\
\hline Level of significance & $* * *$ & $*$ & $*$ & NS & NS & $* *$ & $*$ \\
\hline Least significant difference $(5 \%)$ & 481.3 & NS & 0.39 & NS & NS & 1.0 & 4.8 \\
\hline Year $\times$ intercropping & $*$ & $* *$ & NS & NS & NS & $* *$ & NS \\
\hline Coefficient of variation (\%) & 28.5 & 4.9 & 15.4 & 24.4 & 7.6 & 27.1 & 24.2 \\
\hline
\end{tabular}

*, **,*** Significant at $P<0.05, P<0.01, P<0.001$, respectively; NS $=$ not significant.

$\dagger$ Means in a column with the same letter are not significantly different at $P \leqslant 0.05$.

equivalent ratio was from 0.80 to 0.95 for wheat and 0.08 to 0.37 for faba bean. The higher land equivalent ratios for wheat than for faba bean were expected since selected proportions of the faba bean seed rate were intercropped with the normal seed rate of wheat.

According to Trenbath (1983) and Hiebsch and McCollum (1987), the land equivalent ratio gives a valid estimate of biological efficiency when all intercrop components have equal production-cycle duration, and when planting and harvesting of the intercrop coincide with planting and harvesting of the sole culture checks. In line with this, the two intercrop component crops in our study had more or less similar growth duration. Therefore, the fact that all the intercrops in the present study had land equivalent ratios greater than 1.0 denotes our intercrops were more biologically efficient than sole crops.

According to Holland and Brummer (1999), better resource-use efficiency of intercrops was associated with better growing conditions. However, maximized resource-use efficiency by crop mixtures under both marginal and better growing conditions was also reported (Rosegrant and Roumasset, 1990; Rafey and Prasad, 1991). In the present study, the land equivalent ratio in the high-stress year of 2002 was similar to that of the low-stress year of 2003. Moreover, the year by intercropping interaction for the total land equivalent ratio was not significant, implying a similar pattern of response of the sole as well as intercrop treatments in the two years. In our other studies, we reported similar land equivalent ratios for the two years for barley-faba bean and tef-faba bean intercropping, but a significantly lower land equivalent ratio for the least-stress year of 2001 when compared with the medium- to high-stress years of 2002 and 2003 for the barleyfaba bean intercrop (Agegnehu et al., 2006a, b).

Since the productivity of the component crops may differ, higher land equivalent ratios as such may not necessarily imply higher productivity at the system level. However, in the present study total land equivalent ratios also showed a posi-

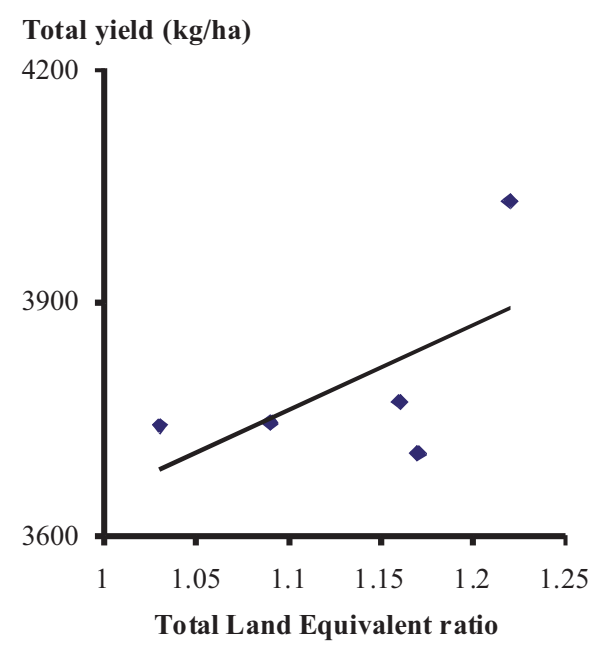

Figure 1. Interrelationships of total land equivalent ratios and total grain yields $\left(\mathrm{kg} \mathrm{ha}^{-1}\right)$ of wheat and faba bean grown under mixed intercropping. $\mathrm{y}=1092.3 \mathrm{x}+2560.7\left(\mathrm{R}^{2}=0.38\right)$.

tive relationship with the total yields of the two crops in the mixture (Fig. 1), implying greater system productivity.

\subsection{Competition among component crops}

In the present study, there was some synergistic effect of intercropping on total productivity, as the total yield and system productivity index of wheat-faba bean intercropping at the seed rate of 100:37.5 exceeded the sole yield of either crop (Tabs. I, IV). Nonetheless, the negative association between the yields of the two crops (Fig. 2) highlights some degree of competition between the crops for space and resources. Hence, improved productivity in one crop as a component of the system may result in yield reduction of the other component. Wheat and faba bean usually have similar growth duration 
Table IV. Relative crowding coefficient $(k)$, product of the coefficients $(K)$, aggressivity value $(A)$ and system productivity index (SPI) of wheat and faba bean grown in intercrops in 2002 and 2003 in Holetta, Ethiopia

\begin{tabular}{lcccccc}
\hline \multirow{2}{*}{ Treatments } & \multicolumn{2}{c}{ Relative crowding coefficient $(k)$} & \multicolumn{2}{c}{ Aggressivity $(A)$} & \multirow{2}{*}{ System productivity index $($ SPI) } \\
\cline { 2 - 5 } & Wheat & FB & $K$ & Wheat & Faba bean & 3896 \\
Wheat/ faba bean (100:12.5) & 2.25 & 0.67 & 1.51 & 0.30 & -0.30 & 4130 \\
Wheat/ faba bean (100:25) & 2.08 & 0.96 & 2.00 & 0.10 & -0.10 & 4629 \\
Wheat/ faba bean (100:37.5) & 4.09 & 1.15 & 4.70 & 0.10 & -0.10 & 4391 \\
Wheat/ faba bean (100:50) & 2.65 & 0.92 & 2.44 & 0.20 & -0.20 & 4433 \\
Wheat/ faba bean (100:62.5) & 2.49 & 0.93 & 2.32 & 0.20 & -0.20 & 4296 \\
Mean & 2.71 & 0.93 & 2.59 & 0.18 & -0.18 & \\
\hline
\end{tabular}

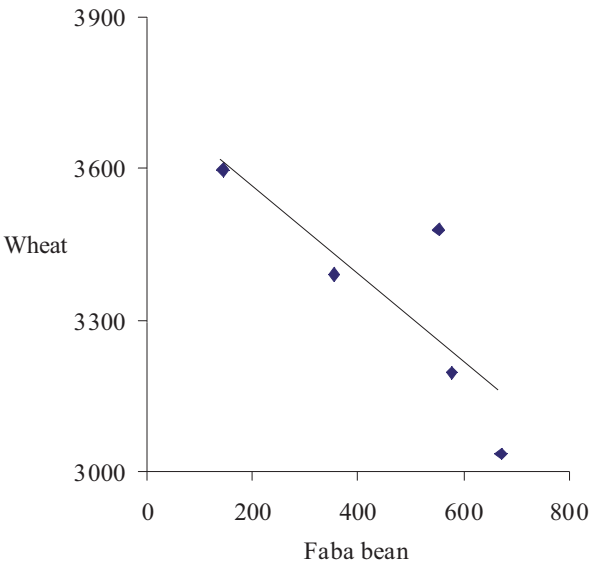

Figure 2. Interrelationships of grain yield of wheat and faba bean $\left(\mathrm{kg} \mathrm{ha}^{-1}\right)$ grown under mixed intercropping. $\mathrm{y}=-0.8745 \mathrm{x}+3742.1$ $\left(\mathrm{R}^{2}=0.67\right)$.

so that when grown together, both crops can utilize resources at the same time, resulting in competition among the component crops. However, intercrop yield advantage may occur because the tap root system of faba bean could exploit water and nutrients from deeper soil layers than wheat. In addition, in a cereal-legume intercropping system cooperation for $\mathrm{N}$ may exist under conditions of nodulation. Such cooperation is manifested in the form of greater yield of a mixture than the sole culture yield of the highest yielding component of that mixture. In mixtures consisting of species with similarities in their needs, competition rather than cooperation can be expected. In this case, mixtures generally yield less than the highest yielding sole culture (Rao and Willey, 1980).

Data on the competitive ability parameters, namely the relative crowding coefficient $(k)$ and product of the coefficients $(K)$, and the aggressivity parameter $(A)$, are given in Table IV. The highest crowding coefficient of 4.70 and system productivity index of 4629 were obtained from the proportion (100:37.5) of wheat/faba bean intercropping in which the highest total yield, land equivalent ratio and gross monetary values were recorded. The values of the system productivity index were high and largely determined by the wheat intercrop, which was not much reduced by intercropping. According to Willey (1979), when a species has a relative crowding coefficient less than, equal to, or greater than one it means the species has produced less yield, the same yield, or more yield than its 'expected' yield, respectively. A crop with relatively lower $k$ and negative $A$ values is regarded as being dominated while one with the opposite values is dominant (Willey, 1979). In our study, all $k$ values of wheat were greater than unity and the $A$ values positive, indicating wheat produced greater yield than was expected and that wheat dominated faba bean in the mixture. This contrasts with our previous reports whereby the weak-strawed tef and also, to a lesser extent, barley, were dominated in their respective mixtures with faba bean (Agegnehu et al., 2006a, b).

\section{CONCLUSION}

High input-based semi-dwarf wheat production is a common feature of crop agriculture in the Ethiopian highlands, a region characterized by high population density, small farm size, low farm income, high rates of soil degradation, and high incidence of crop diseases and persistent weeds. Wheat/faba bean intercropping in the Ethiopian highlands may increase total yields and revenue, break the prevalence of persistent grass weeds associated with high-input monoculture wheat, reduce the incidence of faba bean diseases, lessen the need for external inputs, enhance land-use efficiency and thereby increase the economic and ecological sustainability of crop production. Subsequent on-farm verification of intercropping of $37.5 \%$ of the seed rate of faba bean in full wheat under real farm production conditions should provide socio-economic data on the performance of the intercrop vis-à-vis the conventional sole crop before deriving concrete recommendations.

Acknowledgements: The highland cool-season food legumes project, sponsored by the Royal Netherlands Government and the Ethiopian Institute of Agricultural Research, is gratefully acknowledged for funding this experiment. We are also grateful to Mr. Beyene Ofa and Mr. Ayalew Adella for their technical assistance in the execution of the field experiment.

\section{REFERENCES}

Agegnehu G., Ghizaw A., Sinebo W. (2006a) Yield performance and land-use efficiency of barley and faba bean mixed cropping in Ethiopian highlands, Eur. J. Agron. 25, 202-207.

Agegnehu G., Ghizaw A., Sinebo W. (2006b) Crop productivity and landuse efficiency of a tef/faba bean mixed cropping system in a tropical highland environment, Exp. Agr. 42, 495-504. 
Akter N, Alim A.Md., Islam M.M., Naher Z., Rahman M., Hossain I.M. (2004) Evaluation of Mixed and Intercropping Lentil and Wheat, J. Agron. 3, 48-51.

Banik P. (1996) Evaluation of wheat + legume intercropping under 1:1 and 2:1 row replacement series system, J. Agron. Crop Sci. 176, 289-294.

Beets W.C. (1982) Multiple cropping and tropical farming systems, Gower Publishing Company Limited, Gower House, Aldershit, Hampshire, England.

Benites J.R., McCollum R.E., Naderman G.C. (1993) Production efficiency of intercrops relative to sequentially planted sole crops in a humid tropical environment, Field Crop. Res. 31, 1-18.

Bulson H.A.J., Snaydon R.W., Stopes C.E. (1997) Effects of plant density on intercropped wheat and field beans in an organic farming system, J. Agr. Sci. 128, 59-71.

Carr M.P., Gardner C.J., Schatz G.B., Zwinger W.S., Guldan J.S. (1995) Grain yield and weed biomass of a wheat-lentil intercrop, Agron. J. $87,574-579$.

Central Statistics Authority (CSA) (2004) Agricultural sample survey (2003/2004): Report on area under cultivation yield and production of the major crops, main season, CSA, Addis Ababa, Ethiopia.

Chen C., Westcott M., Neill K., Wichmann D., Knox M. (2004) Row configuration and nitrogen application for barley-pea intercropping in Montana, Agron. J. 96, 1730-1738.

Chu G.X., Shen Q.R., Cao J.L. (2004) Nitrogen fixation and N transfer from peanut to rice cultivated in aerobic soil in intercropping system and its effect on soil N-fertility, Plant and Soil 263, 17-27.

Eyal Z., Scharen A.L., Prescott J.M., Ginkel M. Van (1987) The Septoria Diseases of Wheat: Concepts and methods of disease management, Mexico, D.F., CIMMYT, 52 p.

Georgis K., Abebe A., Negasi A., Dadi L., Sinebo W. (1990) Cereal/legume intercropping research in Ethiopia, Proceedings of a Workshop on Research Methods for Cereal/Legume Intercropping in Eastern and Southern Africa, pp. 167-175, Mexico, CIMMYT.

Haymes R., Lee H.C. (1999) Competition between autumn and spring planted grain intercrops of wheat (Triticum aestivum) and field bean (Vicia faba), Field Crop. Res. 62, 167-176.

Hiebsch C.K., McCollum R.E. (1987) Area-X-time equivalency ratio: A method for evaluating the productivity of intercrops, Agron. J. 79, $15-22$.
Holland J.B., Brummer E.C. (1999) Cultivar effects on Oat-Berseem Clover Intercrops, Agron. J. 91, 321-329.

Jensen E.S. (1996) Grain yield, symbiotic $\mathrm{N}_{2}$ Fixation and interspecific competition for inorganic N in pea-barley intercrops, Plant and Soil $182,25-38$

Kurdali F., Sharabi N.E., Arslan A. (1996) Rain-fed vetch-barley mixed cropping in the Syrian semiarid conditions. I. Nitrogen nutrition using ${ }^{15} \mathrm{~N}$ isotopic dilution, Plant and Soil 183, 137-148.

Li L., Yang S., Li X., Zhang F., Christie F. (1999) Interspecific complementary and competitive interactions between intercropped maize and faba bean, Plant and Soil 212, 105-114.

Odo P.E. (1991) Evaluation of short and tall sorghum varieties in mixtures with cowpea in the Sudan savanna of Nigeria: Land equivalent ratio, grain yield and system productivity index, Exp. Agr. 27, 435-441.

Ofori F., Stern W.R. (1987) Cereal-legume intercropping systems, Adv. Agron. 41, 41-90.

Rafey A., Prasad N.K. (1991) Biological potential and economic feasibility of intercropping oilseeds and pulses with safflower (Carthamus tinctorius) in dry lands, Indian J. Agr. Sci. 61, 893-897.

Rao M.R., Willey R.W. (1980) Evaluation of yield stability in intercropping: Studies on sorghum/pigeonpea, Exp. Agr. 16, 105-116.

Rosegrant M.W., Roumasset J.A. (1990) Effect of nitrogen on pigeon pea (Cajanus cajan) and rice (Oryza sativa) intercropping system, Indian J. Agr. Sci. 60, 519-522.

SAS Institute (2001) SAS/STAT user's guide, version 8.2, SAS Inst., Cary, NC.

Singh S.B., Singh B.N., Maurya M.L. (1992) Comparative performance of mixed and intercropping systems with different winter crops under diara land conditions, Indian J. Agron. 37, 40-43.

Trenbath B.R. (1983) Plant interactions in mixed crop communities, Multiple Cropping, ASA special publication No. 27, USA, pp. 129171.

Tsubo M., Walker S., Ogindo H.O. (2005) A simulation model of cereallegume intercropping systems for semi-arid regions II. Model application, Field Crop. Res. 93, 23-33.

Willey R.S. (1979) Intercropping - its importance and research needs, Part 1, Competition and yield advantages, Field Crop. Abstr. 32, $1-10$. 